\title{
EROS, HISTÓRIA E UTOPIA: O TEATRO DE NATÁLIA CORREIA ${ }^{*}$

\author{
Eros, history and utopia within Natalia Correia's \\ plays
}

\author{
Armando Nascimento Rosa**
}

Onde se solta o estrangulado grito Humaniza-se a vida e sobe o pano. Chegam apariçôes dóceis ao rito Vindas do fosso mais fundo do humano.

Ilumina-se a cena é é soberano, no palco, o real oculto no conflito. É tragédia? É comédia? É, por engano, o sequestro de um deus num barro aflito?

É o teatro: a magia que descobre 0 rosto que a cara do homem cobre; E reflectidos no teu espelho - o actorOs teus fantasmas levam-te para onde o tempo puro que te corresponde Entre horas ardidas está em flor.

NATÁLIA CORREIA, Sobe o pano

(soneto para as comemoraçóes do Dia Mundial do Teatro de 1993)

\footnotetext{
Texto revisto de uma conferência proferida em 27 de Março de 2003 (Dia Mundial do Teatro), em Lisboa, integrada no Colóquio Natália Correia (que assinalou o $10^{\circ}$ aniversário da morte da escritora), realizado na Faculdade de Ciências Sociais e Humanas da Universidade Nova de Lisboa.

Dramaturgo, ensaísta e professor na Escola Superior de Teatro e Cinema do Instituto Politécnico de Lisboa; doutorado em Literatura Portuguesa Dramática - séc. XX -, pela Universidade Nova de Lisboa).
} 
Nome maior da Literatura Portuguesa, Natália Correia (S. Miguel, Açores/1923-Lisboa/1993) é uma luz irradiante na pólis cultural do Portugal novecentista. Militante combativa da palavra e da irreverência poéticas, a versatilidade da sua obra literária reparte-se por uma diversidade de géneros que englobam a narrativa romanesca, o teatro, o ensaio literário e/ou historiográfico, a prosa autobiográfica e diarística, o libreto operático, a fiç̧ão infanto-juvenil, a intervenção jornalística, a tradução/recriação, o guião televisivo (documentarismo), o discurso parlamentar (foi deputada à Assembleia da República, depois da revolução de 1974, em várias legislaturas) e, impregnando tudo o que escreveu, a poesia nos seus mais diversos registos: desde a experimentação surrealista e a reabilitação da sátira, passando pela reinvenção das estéticas romântica e barroca, até se deter na forma clássica do soneto (em que ela foi mestra, numa tradição que a emparceira com Camóes e Bocage, Antero de Quental e Florbela Espanca), para compor o seu literário testamento de autognose, a três anos da morte física (o livro Sonetos românticos, de 1990, que receberia o Grande Prémio de Poesia da Associação Portuguesa de Escritores).

Nascida na ilha atlântica de S. Miguel, a maior dos Açores, que a lenda associa ao coração emerso da mítica Atlântida de Platão, é desde muito jovem que Natália se fixa em Lisboa (em 1935, curiosamente o ano da morte de Fernando Pessoa), com a mãe e a irmã, trazendo consigo as memórias mágicas do seu espaço natal, uma mente brilhante e irrequieta de autodidacta, e uma extraordinária beleza, a um tempo afrodítica e andrógina, que fizeram dela um icone vivo, incendiador de paixões. Mulher libertária, desafiando os preconceitos dos tempos históricos que atravessou, o segredo do fascínio que emanava parecia, porém, provir de épocas ancestrais, da sua idealizada Grécia amada, de uma nostalgia matriarcal mediterrânica que a fazia apóstola poética do politeísmo antigo, responsável pelo nascimento do teatro ocidental. De Natália havia de dizer Henry Miller, quando se conheceram pessoalmente: «Foi preciso vir a Portugal para encontrar uma verdadeira pitonisa." (DACOSTA, 2001, p. 176). Entre a disciplina intuitiva ou cerebral e o excesso dionisíaco de "genial fabricante de sonhos» (SANTOS, 1993, p. 2), Natália foi musa inspiradora dos outros e de si mesma; irmã espiritual de Lou Andréas Salomé, conseguiu ser tão bombástica e polémica, na sua auto-encenada persona, como o é hoje, por exemplo, uma Camille Paglia.

Entre 1952 e 1989, Natália Correia produz uma obra dramatúrgica, composta por quinze títulos, que por certo lhe concede o título do mais original e audacioso dramaturgo português da segunda metade do século $X X$. Lugar de experimentação híbrida de formas, e não obstante o silenciamento cénico (e também editorial) de que é vítima durante o salazarismo (e 
não só), o teatro escrito nataliano evolui e viaja por uma impressionante diversidade de registos genológicos e estéticos: da fábula surrealista, infanto-juvenil (Dois reis e um sono, 1958) ou adulta (Sucubina ou a teoria do chapéu, 1952), ao absurdismo em sátira política (O homúnculo, 1965); do drama existencial pós-simbolista (D. João e Julieta, 1957-58) ao mitodrama filosófico ou auto-referencial (o progresso de Édipo, 1957, e Comunicação, 1959); do teatro épico-catártico pós-brechtiano e pós-artaudiano (A pécora, 1967 e O encoberto, 1969) ao teatro histórico-mítico, que colige o pathos romântico com o estranhamento da alegoria barroca (Erros meus má fortuna, amor ardente, 1980); do libreto operático sociocrítico (Em nome da paz, 1973, com música de Álvaro Cassuto) ao drama antropológico e arquetípico (Auto do solsticio do inverno, 1989); do texto para cantata cénica (O romance de D. Garcia, 1969, com música de Joly Braga Santos) ao teatro versificado ou em prosa que revisita temas da tradição literária e do romanceiro $(A$ juventude de Cid, A donzela que vai à guerra, e D. Carlos de além-mar, três peças de datação incerta).

As evasóes e invasóes de eros, os fascínios e as prisóes do tempo histórico, e as utopias do humano projectadas na cena são pistas para o mapa da dramaturgia nataliana édita e inédita. Testemunha subversiva do meio século de ditadura em que Portugal viveu, Natália dramaturga é bem um caso exemplar dos efeitos castradores que a censura infligiu numa arte pública como é a teatral, e que em Portugal carrega, além do mais, o estigma histórico de três séculos de Inquisição. Como autora exilada do palco, a sua persistência na forma dramática resulta de uma vocação teatral inadiável que, por isso mesmo, não deixará de denunciar a asfixia criativa a que estiveram votados os dramaturgos portugueses mais representativos deste extenso periodo, entre os quais se destaca Bernardo Santareno (1920-1980). Natália não cessa de compor dramas para o eco morto da gaveta ou, na melhor das hipóteses, para a cumplicidade conspiratória da leitura partilhada, nesse espaço de tertúlia cultural e resistência política em que se constitui a sua casa de Lisboa, nas décadas de 1950 e 1960. Lugar onde se leva à cena privada, pela primeira vez em Portugal, o Huis Clos de Sartre, sob a direcção de Carlos Wallenstein, em cujo elenco se integra a escritora anfitriã, a par do amigo e dramaturgo Manuel de Lima (1918-1976), com cuja colaboração Natália Correia principia a sua experiência como autora dramática, com o divertimento surrealizante Sucubina ou a teoria do chapéu (1952); peça considerada perdida durante anos, mas cujo dactiloscrito original viria a ser descoberto na íntegra, de entre o espólio literário da autora, depositado na Biblioteca Nacional, em Lisboa.

Embora Natália minimizasse este texto (resistindo a divulgá-lo, segundo o confidencia a Júlia LELLO, em 1988), o que é facto é que, decor- 
rido que foi meio século sobre a sua escrita, o mínimo que se pode falar é de uma sensação de espanto perante uma tão sedutora e consistente estreia desta dupla de autores, nos domínios do teatro escrito. Sucubina ou a teoria do chapéu (STC) é uma peça em quatro actos, que respira um prazer intenso pela construção dialogal e pela contracena que lhe é inerente, perpassada por uma elegância e subtileza no estilo e pelo desassombro modernista do olhar crítico (concretizando a acepção de Harold Bloom, que entende o modernismo como um romantismo tardio), com sub-reptícias mensagens simbólicas, próprias de uma criação literária vígil em tempo de ditadura. Experimento assumidamente paródico, a peça apropria-se do imaginário demonológico para o subverter, numa espécie de moralidade surreal, com ingredientes romanescos e policiários. O primeiro acto decorre no Inferno, mas trata-se de um Inferno nada ígneo, mais entediante e burocrático do que imediatamente assustador, onde os diabos mantêm conversas de salão, demasiado humanas, convergindo por vezes, no seu faustiano pastiche, com os climas de ironização dialogal de um romance escrito também sob um regime totalitário: Margarita e o mestre, de Mikhail Bulgakov (concluido em 1940, mas só publicado na U.R.S.S. em 1966). Assim, em vez de citar as chamas tradicionais do Inferno medieval, o espaço cénico apresenta antes uma "vasta sala sem mobiliário a não ser um cravo cujo respectivo banco é um velocípede» e "ao centro, uma janela", da qual partem, de cada um dos lados, "duas escadarias que se perdem no infinito" (STC, $p .1$ ). E como o nome do príncípe caído é legião, segundo a letra bíblica, assim a peça faz jus a essa multiplicação: temos um Satã líder que toca cravo para se acalmar, e diz que os seus súbditos pares infernais "estão corrompidos pela humanidade» (STC, p. 5); uma Súcubo revoltada com a sua condição de mera aparência eterna, controlada por Satã (alusão de feminista sátira ao Eterno Feminino goetheano por ela representada), a suplicar incessantemente pelo chapéu certo para o seu figurino (e dai o título da peça); um Lúcifer folgazão que procura um cachimbo; e um Satanás que exige sem demora que lhe arranjem um lacaio para carregar a sua mala, cada dia mais pesada - como se fosse, avant la lettre, um sádico Pozzo de À espera de Godot (1953) sem ter encontrado ainda o seu Lucky. A estas figuras de teatro, junta-se Deodata, uma solteirona que faz tricote contraria a etimologia latina do seu nome (a Deus dada), reclamando por já ter expirado o prazo da sua estadia no Inferno. A trupe dos mafarricos eternos, subalternos de Satã, torna-se entretanto sensivel à substância do tempo e, tal como Deodata (que tenta subornar os diabos para se evadir daquele Inferno moroso e pseudo-kafkiano, de hierarquias corporativas em que nada se altera), também eles suspiram por uma viagem ao mundo dos vivos, para satisfazer os seus desejos pessoais. 
De tal modo assim é que os três actos consequentes terão todos lugar na muito terrena estalagem da D. Briolanja, onde se encontra hospedado há muito um idoso e tenaz trabalhador, chamado Sr. Querubim de Nascimento; figura aparentemente apagada que se suspeita pelo nome ser um funcionário ao serviço de Deus, até porque os anjos danados hão-de dizer-se seus admiradores desde sempre. Florindo, filho de Briolanja, a proprietária da estalagem, é um jovem idealista que compóe com o som de sinos um tipo de música que é temida pelos dois íncubos recém-chegados, mas será despertadora do amor em Sucubina, aprendiz de humana - um aspecto pelo qual ela nos lembra, em paródia surreal e metafísica, essa Inês em peregrinação terrena, filha do deus Indra, que protagoniza Um sonho (1901), de Strindberg. Os três diabos viajantes mudaram entretanto de nomes próprios, para humanizarem o disfarce da sua nova identidade: Súcubo é Sucubina; Satanás é Santanazo; e Lúcifer passa a ser Luciferro. Santanazo quer logo fazer de Florindo o seu lacaio, carregador da mala; Luciferro cobiça o cachimbo austríaco de Querubim; e Sucubina persiste na busca por um metonímico chapéu ideal. Uma preocupação comum a esses anjos caídos reside na procura teatral de uma psicologia que seja adequada aos personagens que representam na cena vivente; oportunidade para falas de deliciosa sátira psicossocial (2० acto).

LUCIFERRO: Deixa-te de lições. Eu só acredito no que vem no jornal. Foi para isso que eu mudei de ambiente.

SANTANAZO: Eu cá só me deixo convencer pelo aspecto das pessoas. Se assim não fosse ficava lá onde não havia fisionomias.

SUCUBINA: Não sejam idiotas. Convençam-se que ainda têm muito que aprender. Tu e o Luciferro desde que aqui chegaram só têm cometido imprudências. Vocês não sabem falar a língua desta gente. Têm que me dar ouvidos. Eu conheço-os. Se descobrem quem somos fazem para aí uns exorcismos que nem a pele se nos aproveita.

SANTANAZO: Espero que isso não aconteça. Este mundo é muito agradável. As pessoas têm várias caras.

SUCUBINA: Queres dizer caras diferentes. Mas não te entusiasmes. primeiro que tudo o que nós temos é de criar uma personalidade. Isto é... condensar a nossa força dentro de uma noz.

LUCIFERRO: Sim... Criar um temperamento.

SANTANAZO: Eu já escolhi o meu temperamento. A psicologia que me convém é esta: pôr os outros a trabalhar para mim e tirar dai o rendimento dum grande prestígio. O trabalho é uma anomalia. Nasce-se trabalhador para não morrer de fome e morre-se de qualquer outra coisa. Os que percebem isto vão parar a um manicómio. E quem não perceber isto tem mentalidade de formiga (STC, $2^{\circ}$ acto, p. 6-7). 
Magnetizada pela beleza da música dos sinos e do discurso convicto de Florindo, Sucubina, que viaja como mulher de Luciferro, acaba por descobrir o amor correspondido na alma desse jovem inconformista; sentimento humano que não será bem visto pelos demónios que a acompanham. Ainda assim, quando Santanazo planeia um estratagema para eliminar Florindo, fá-lo pelo facto de este se ocupar em tanger os sinos, som simbólico de um divino sublime que afugenta qualquer mafarrico que se preze. $O$ impulso de eros faz com que Florindo revele a Sucubina o idealismo esotérico da sua arte incompreendida.

\begin{abstract}
FLORINDO: Eles nem sequer sabem o que é um sino... Um sino não éo que eles pensam. O que o constitui não é a forma que reveste na sua massa, nem mesmo o som com que fere o ar. São as suas harmonias com a consciência, as artes, a pátria, a natureza, a sociedade... Voz para o Oriente, voz para o Ocidente... voz do sul e do setentrião... (STC, $2^{\circ}$ acto, $p$. 16).
\end{abstract}

Para calar a voz do artista Florindo, Luciferro e Santanazo induzirão para sua cúmplice uma outra hóspede da estalagem, já conhecida pelo leitor/espectador: a solteirona Deodata, estereótipo da megera castradora, que inveja o amor de Florindo e Sucubina. Santanazo explora o lado mais frustrado e mesquinho do seu temperamento de delatora. D. Briolanja divulgara um pesadelo agoirento que frequentemente a visita, e em que o voo de uma ave negra junto às torres assinalaria a morte do filho músico. Santanazo oferece então umas asas negras para Deodata se disfarçar de ser alado, $e$ será ela o falso avejão que conduz Florindo à queda mortal, numa encenação literal do sonho mau de Briolanja. Deodata, antagonista de Sucubina, tipifica uma condição feminina prisioneira de si mesma, de dedo moralista acusador das acçôes que sempre desejou mas nunca ousou praticar. «A sua alma é um pássaro que ficou engaiolado nas grades do celibato" (STC, $3^{\circ}$ acto, p. 7), dir-lhe-á o saber diabólico de Santanazo. Avejão é bem o termo que se aplica ao rosto interior desta personagem caricatural, que se diz perseguida pelo diabo (que "pode ser até a própria consciência", segundo o diz Florindo no $2^{\circ}$ acto, $p$. 20) e que aparecerá de novo como a Solteirona do nataliano Auto da feiticeira cotovia (1959); a sua erofobia ecoa a velha moribunda da peça homónima de Raul Brandão (O avejão, 1929), uma falsa cristã que não experimentara em vida a fruição erótica por impotência e hipocrisia comportamentais.

No quarto acto comparece o Inspector, que vai interrogando, em jeito policial, os diversos personagens, potencialmente suspeitos da morte de Florindo. Na sequência dos diálogos cruzados, Sucubina dará a entender 
o que pode significar para ela a busca desse chapéu surreal que nomeia a peça; chapéu aliás que se materializara na cena de encontro amoroso que abre o $3^{\circ}$ acto, em que Florindo, num gesto de simbólica dádiva edipiana, oferecera a Sucubina um belo chapéu de plumas, com quarenta anos, que pertencera à sua mãe. E como dirá agora Sucubina, a teoria do chapéu vem a ser «o caso comum da mulher que quer ter o direito ao sonho. A um sonho de amor" (STC, $4^{\circ}$ acto, $p$. 10). Por isso ela saiu do Inferno dos demónios para a esfera dos vivos, para concretizar o seu sonho. Um paralelismo sinistro é terem também os seus comparsas concretizado o pesadelo filicida de Briolanja, descontente com a inadaptação lírica do filho ao mercado de trabalho (pois o artista Florindo é um desempregado por opção própria). A busca pelo autoconhecimento por meio da realização do sonho inconsciente é uma chave fundamental da peça; e o inconsciente é bem o lugar onde habitam os nossos demónios mais profundos. Saber dar voz ao dáimon sem torná-lo demoníaco (isto é, sem que ele se torne um agente destrutivo) foi a tentativa vã de Sucubina, como ela própria o reconhece - ao responder ao senso comum reducionista de Deodata -, pelo pacto nocivo que estabeleceu com os dois íncubos que a escoltaram ao palco dos vivos.

\begin{abstract}
DEODATA: Porque é que não fez como as pessoas normais. Porque é que não se contentou com aquilo que era?

SUCUBINA: Todos sonham o que são. E assim não há progresso. Porque não entendendo o que são não podem entender o sonho. Eu quis ser o que sonhava. Quis aprender o que era. (pausa) Agora vou entrar no lado vergonhoso da minha confissão. Para viver o meu sonho eu tive que fazer um pacto com a realidade: o cachimbo de Luciferro e a ambição ociosa do sr. barão de Santanazo (STC, p. 10).
\end{abstract}

Mas o Inspector parece sempre saber mais do que os depoimentos que cada um lhe vai prestando. Por invocar a frase do inicio (ao perguntarse até que ponto Santanazo e Luciferro se deixaram "corromper pela humanidade»), percebemos que se trata de Satã oculto na identidade do Inspector; desafiando a memória das origens naqueles três personagens infernais que se fazem passar por tão humanos como humana é a sua acólita Deodata. Uma fala interpelante do Inspector antecipa a desconstrução final do enredo, introduzindo o arquétipo gnóstico da interrogação pelas origens, e as respectivas fugas para o sujeito se furtar a essa esfinge questionadora.

INSPECTOR: (...) Claro. Não pensam nada. Para pensarem teriam de se lembrar donde vinham. ofantasma da nossa origem é um 
ROSA, A. N. EROS, HISTÓRIA E UTOPIA:...

\begin{abstract}
monstro que se afoga em esquecimento, não é? o vinho... (aponta Santanazo) of fumo... (aponta Luciferro) o amor... (aponta Sucubina) qualquer destas três formas de embriaguês se fosse possivel até faria esquecer ao diabo a sua própria origem. Vistas bem as coisas porque é que eu não hei-de ser um Inspector? A falha de memória que vos levou a aceitar-me como tal podia ser aproveitada por mim para me apresentar com qualquer outra identidade. Numa sociedade em que os homens estão esquecidos de si mesmos, qualquer aventureiro pode ser até um rei se declarar que é um rei. Portanto, meus senhores, nada impede que eu seja o Inspector (STC, $4^{\circ}$ acto, p. 11).
\end{abstract}

Dá-se então o golpe de teatro final, como n' A ilusão cómica, de Corneille: o até ai pacato Querubim mostra agora todo o seu magno poder de encenação e impede que este Inspector se mantenha em funções. "Apagam-se as luzes subitamente» (STC, p. 11) por ordem de Querubim, e quando se acendem, o Inspector já saiu de cena. Tudo não passou de uma sessão de leitura, materializada em representação do ponto de vista do público. Querubim é, como um Próspero tutelar, o autor/leitor de um manuscrito que fecha entre as mãos nesse momento, enquanto "as outras personagens estão sentadas na sala em atitude de quem acaba de ouvir uma leitura» (STC, $4^{\circ}$ acto, $p$. 12). Todos são afinal hóspedes em férias na estalagem de Briolanja, e a ironia derradeira é digna de uma sofisticada comédia póspirandelliana, que baralha os dados do universo de ficção antes criado diante do espectador. "Ouve-se o barulho dum carro que pára»; é o filho de Briolanja que chega de viagem, nada mais nada menos do que Florindo, um jovem estudante que Sucubina elogia como "grande artista». Florindo é um executante de cravo (o teclado de Satã, apresentado no $1^{\circ}$ acto) e a peça termina no momento em que ele se prepara para explicar a Sucubina as razóes do seu interesse por esse «instrumento longínquo para a nossa época» (STC, $4^{\circ}$ acto, $p$. 13).

Nesta surpreendente Sucubina, que não merecia a gaveta escondida a que os autores a relegariam, já se encontra bem vincada uma característica comum a todo o teatro nataliano, e que tem na Idade Moderna o seu paradigma tutelar em Shakespeare: falo do teatralismo; que se manifesta num jogo permanente com os mecanismos intrínsecos à gramática com que se urde a mimese teatral, numa dialéctica que em Natália passa pelo gosto barroco de fazer e desfazer a ilusão dramática. E talvez o tempo de recepção desta peça, habitada por demónios muito humanos, seja o nosso, se se atentar nas palavras premonitórias que Florindo diz a Sucubina (projecçóes paródicas prováveis da dupla autoral, nomeadamente por Florindo ser um músico tal como Manuel de Lima também o era, e Sucubina uma romântica 
vamp, com corte poliândrica que a disputa, à imagem da máscara de femme dominatrix sob a qual Natália se protegeu), depois de a presentear com o chapéu de plumas; palavras que são também a expressão de uma asfixia cultural vivida na sociedade portuguesa do tempo da sua escrita.

FLORINDO: Isto ainda não é nada. Tenho muito mais para te oferecer... a minha sinfonia do futuro. Sim... porque futuro é a única palavra que está de acordo connosco. Não é verdade que nós somos contra o presente? Não nos é possível aceitar o que se passa aqui. Não podes viver toda a vida ligada a um doido... (STC, $3^{\circ}$ acto, $p$. 1)

Mas uma peça teatral pode ser vista em antitese a essa garrafa de vinho da colheita de 1923 (data auto-referencial, por ser o ano de nascimento de Natália) que produz em Sucubina o seguinte aforismo: "Os homens póem o tempo dentro duma garrafa para se esquecerem do tempo" (STC, $2^{\circ}$ acto, $p$. 15). A latência virtual do texto dramático não somente contraria o esquecimento do tempo como o transcende, ao proceder à reinvenção de um tempo outro por intermédio do tempo mesmo da representação cénica; o tempo do teatro é memória activa e liberação criativa.

A mesma dupla de autores que compôs esta até hoje desconhecida Sucubina conseguiria anos depois lograr uma ousadia inusitada para $o$ regime político de então: uma primeira peça que se vê representada em palco, por intermédio do disfarce dramatúrgico de teatro infantil, em 1958, aproveitando decerto o sono ignaro dos censores. De facto, Dois reis e um sono (cuja cópia do dactiloscrito inédito me chegou inicialmente às mãos graças ao labor investigativo da teatróloga Eugénia Vasques) é uma parábola, plena de teatral eficácia, que bebe simultaneamente na fonte dos contos tradicionais e na camuflada herança das cortes loucas imaginadas por Alfred Jarry e seus Ubus. Estreou-se em Lisboa no já demolido Teatro Monumental, pelo Teatro Gerifalto (companhia de teatro para a infância, 19561974), com elenco de jovens actores promissores que ofuturo confirmaria (Fernanda Montemor, Rui Mendes, Mário Pereira, etc.), sob a direcção do encenador e escritor António Manuel Couto Viana (1923-), com cenário e figurinos do poeta e artista plástico Mário Cesariny (1923-2006), figura de proa do movimento surrealista português. Trata-se de uma fábula surrealizante sobre o poder que, embora apresente ressonâncias claramente endereçadas ao espaço político nacional (e não só) da época (veja-se o rei sem sono que ressoa de imediato a divisa de general sem medo, como era conhecido Humberto Delgado, malogrado candidato às eleições presidenciais desse ano de 1958, que fizeram tremer Salazar), consegue manter viva uma forte pertinência temática, graças ao teor intemporal do enredo. Dividida em 
três actos, com o subtitulo de Há grande complicação na corte do mandrião (que seria, segundo me testemunhou Couto Viana, o título original da peça, considerado por este demasiado longo e por isso terá o encenador sugerido o nome Dois reis e um sono, com a concordância dos autores), constitui-se formalmente numa alternância sugestiva entre falas em prosa e notáveis trechos versificados que facilmente poderão ver-se cantados pelos personagens, caso a encenação o deseje. E foi o que aconteceu com a realização de estreia, com música composta pelo co-autor Manuel de Lima (embora se ignore hoje o paradeiro das partituras, transcritas por Carlos Manaças). A forma actual que o texto apresenta seria o produto de um trabalho de dramaturgia conjunta, por iniciativa de Couto Viana, que abreviou a extensão verbal da versão originária (que não figura no espólio), com vista à representabilidade.

Como o nome da peça o indica, Dois reis e um sono (DRS) contanos a história de dois reinos em litígio, sendo a alegórica figura do Sono o motivo da discórdia entre monarcas irmãos, o Rei-sem-Sono e o Rei-comSono, este assistido de perto pelo seu ministro Pencudo. A corte do rei dorminhoco ocupa o espaço da acção, apresentado de início pela figura mefistofélica do Sr. Facilita Tudo, personagem que integra em si uma paródia circense à felicidade falsa prometida pelo fundamentalismo consumista, jogada no registo de autoconsciência teatral próprio de um cicerone barroco, ou brechtiano.

SR. FACILITA TUDO: (...) (Dá uma gargalhada sinistra) Aqui onde me vêem, sou o sr. Facilita Tudo... Personagem de grande utilidade como o meu nome indica. Estou pronto a desempenhar todos os cargos e a sair-me bem das missóes mais dificeis... que para dizer a verdade são as únicas que me interessam. Ao pé de mim ninguém se aborrece e ninguém precisa de pensar. Basta vir ter comigo e... pronto... Tudo se arranja. O sr. está triste? Venha cá se quer ficar alegre. O sr. está alegre? Venha cá se quer ficar triste. O sr. é baixo? Venha cá se quer ficar alto. O senhor é magro? Venha cá se quer ficar gordo. E se não sabe o que quer, desde que venha ter comigo fica logo a saber. Nunca deixei de encontrar uma solução genial. (...) O segredo do meu negócio é ter tudo o que as pessoas precisam... E se não precisam, trato de as convencer... Porque o negócio é que não pode parar... (DRS, p. 1-2).

Mas Facilita Tudo é, como se depreende, o personagem que corporiza em simultâneo o mercador astuto e o mago prodigioso (embora inconfiável), capaz de solucionar problemas graves como o de Joaninha, filha do Ministro Pencudo, súbdito do Rei-com-Sono. Joaninha não tem voz, para 
desgosto do seu amado João, que trabalha para o ministro narigudo (espécie de político Pinóquio mentiroso); mas João não tem meios para comprar um bem tão precioso. O dinheiro que lhe puseram nas mãos destina-se a adquirir um creme que faça diminuir o nariz descomunal do seu amo, que, incapaz de assoar-se, sofre de constipação crónica. Facilita Tudo dissuade o jovem de cumprir a missão e promete vender-lhe, dentro de uma caixa-demúsica, uma bela voz para João oferecer à sua Joaninha. A voz de que Joaninha se encontra privada, impedindo-a inclusive de verbalizar o que sente por João, é uma referência legivel à censura política que proíbe a liberdade de expressão no Portugal de então (ainda mais tratando-se de uma mulher), tal como a fala do vendedor o testemunha.

FACILITA TUDO: Aqui tem. Mas cuidado. Veja lá como vai utilizar essa preciosa mercadoria. Uma voz é um instrumento muito delicado. o que perde as pessoas é falarem de mais. (Tosse) (DRS, $p$. 28)

No entanto, Facilita Tudo gosta de complicar, e diverte-se enganando o pobre cliente. Em vez de levar a voz humana à sua Joaninha, João oferece-lhe sem o saber a voz de um cão; e ela troca a mudez absoluta pelos latidos caninos que envergonham publicamente o seu pai ministro, e acabam por despertar o Rei-com-sono. Paralelamente a este imbróglio, a cena é invadida pontualmente por um patético cortejo nupcial, com noiva, pai, fotógrafo e convidados, sempre chegados em hora imprópria para realizar a cerimónia. Trata-se da noiva do Rei-com-sono, que há cinquenta anos espera o momento de casar-se com ele, mas não há maneira de o encontrar acordado para poder haver enlace. Aqui vemos nós uma sátira que Natália e Manuel de Lima fariam a Salazar, ditador celibatário, que promoveu um sono autoritário, narcotizador do país. Entretanto, no desenrolar das peripécias, após o confronto cómico entre João e o Ministro Pencudo por causa de Joaninha, que ladra sem descanso, os dois acabam por aliar-se para se vingarem de Facilita Tudo. Como o Sono é a figura disputada entre ambos os reis em conflito (o Rei-sem-sono, exige partilhar com o rei dorminhoco a faculdade de dormir, que não existe no seu reino), João consegue convencêlo a esconder-se numa arca e fecha-o lá à chave. É então que Pencudo, num típico golpe de teatro, se disfarça de Sono e Joáo tenta vendê-lo a Facilita Tudo, aliciando-o com essa "oportunidade de fazer o melhor negócio da sua vida». (DRS, $p$. 45) Em troca, João exige-lhe a voz humana para dar a Joaninha. Desta vez, como numa volta-face de commedia dell'arte, Facilita Tudo é ludibriado e acabará por ficar no final como servo de João, para poder salvar a pele na nova conjuntura em que João, herói da fábula, casa com 
Joaninha falante e é feito ministro pelo Rei-com-sono, como prémio por revelar a este o paradeiro do Sono desaparecido.

o tema da vanidade e da usura do poder (patriarcal), que será recorrente na dramaturgia nataliana, encontra-se já bem traçado nesta peça imaginativa e sociocrítica, que estabelece um diálogo retrospectivo com a estreia literária da autora, ocorrida no registo ficcional infanto-juvenil: Grandes aventuras de um pequeno herói (1945); uma quadra dita ou cantada por João (personagem para quem o amor é a «coisa mais valiosa, a única verdadeira no mundo", DRS, $p$. 60) sintetiza essa ideia da ambição pelo poder como perdição individual: "Quem quiser não sentir medo / E ser maior que um gigante / Só tem que ter um segredo / Não ser pessoa importante». (DRS, p. 40).

No ano anterior ao da estreia cénica de Dois reis e um sono, Natália publica o progresso de Édipo, a sua primeira peça a solo, em edição de autor (Lisboa, 1957), com um desenho seu na capa, em que um ser hibrido de mulher inteira e esfinge abraça, devoradora, um suposto Édipo; um carvão a testemunhar a faceta de pintora, que Natália Correia cultivou de forma intermitente e catártica. O progresso de Édipo (PE), com o subtítulo de Poema Dramático, reescreve o mito grego transgredindo as suas coordenadas clássicas, à boa maneira do individualismo romântico e da subjectividade surrealista (universos estéticos nos quais Natália se revê). Literariamente soberbo, o texto desta peça mitocrítica, curta mas muito densa, ensaia um moderno mimetismo ante o estilo austero e conciso dos tragediógrafos, recheado com máximas reflexivas, logo prefiguradas no preâmbulo à peça, escrito numa prosa oracular, plena de poesia e enigma.

São quatro os personagens: Tirésias, Édipo, Jocasta e a figura colectiva do Coro, que intervém com uma economia verbal assinalável, numa distribuição de seis breves cenas cuja legenda de sentido é indicada por epigrafe de Nietzsche, oriunda d' O nascimento da tragédia, num passo em que ofilósofo-poeta aborda a hybris fáustica do incesto edipiano.

No entanto, a peça contraria elou baralha as punições destinadas tradicionalmente aos protagonistas. Édipo surge desde o início com analogias à condição de sábio, apto mesmo a rivalizar com o xamã Tirésias.

TIRÉSIAS: Difícil é esgrimir contigo usando estas palavras que os mortais fabricam para comunicarem. Porque tu decifraste o enigma da esfinge e por isso és conhecido como sábio (PE, p. 13).

Um dado fundamental que Natália altera no mito, e que se mostra extremamente significativo na sua reinterpretação de Édipo, consiste na 
origem da cegueira deste. Aqui não é a descoberta das núpcias incestuosas que conduz Édipo a cegar-se. A cegueira é anterior e não auto-infligida, resultando da luta corpo-a-corpo na qual Édipo mata Laio e, mesmo que involuntariamente, abre o caminho para o trono de Tebas. Somos confrontados de novo com o preço faustiano e alienante a pagar pela aquisição do poder exterior sobre os outros: a perda da alma. É o próprio Édipo que o diz ao coro.

ÉDIPO: ... O caso é que um trono não se obtém de graça. Para chegar a ele quase todos contraem a cegueira da alma. É uma cegueira que eles provocam para que o coração não seja um hóspede demasiado importuno no peito de um monarca. Mas eu não matei Laio para lhe usurpar o trono. Porém está escrito que aquele que mata é herdeiro do homem que matou (PE, p. 17).

Esta cegueira antecipada modifica a relação entre Jocasta e Édipo; ele já é cego no momento de desposá-la e dai as dúvidas que assaltam Jocasta por não saber que tipo de projecção amorosa o seu marido cego coloca nela. De facto, a peça nataliana pode ser vista como uma variação do mito edipiano que desenvolve fulcralmente o complexo de Jocasta. Todos os dias ela se desloca ao templo, para pedir aos deuses que restituam a visão a Édipo, mas, como o diz Tirésias, não é por amor dele que ela ofaz, mas para se assegurar da solidez do laço que o une a Jocasta. A sua súplica será atendida; Édipo recupera a vista, que é o símbolo da sua consciência individual. Na anagnórise da identidade de ambos, ele interroga-se, num distanciamento enunciativo, sobre a sustentabilidade da união anómala, agora que o desejo é dilacerado pela evidência do incesto.

ÉDIPO: ... O mamilo róseo perderá a cor na boca do amante. Porque este já não ignora que aquela fonte de volúpia é o mesmo seio que o amamentou. Poderá Édipo transformar as entranhas que o conceberam na terra mais apetecivel às violentas sementes do seu orgasmo? (PE, p. 32)

O elemento trágico neste drama não está propriamente no reconhecimento do incesto (embora não o nomeie, Jocasta de resto já o sabia durante a cegueira de Édipo), mas sim em saber como continuar a viver nele. Lido em literalidade, o desfecho será uma surpresa de feminina crueldade possessiva. Jocasta fere de novo os olhos de Édipo para que ele regresse à noite da cegueira, bem como à dependência que esta impõe, de modo a não perdê- 
lo de si. o progresso de Édipo acaba por expor uma aporia erótica; se, como diz Édipo, "nenhuma viagem nos permite verdadeiro regresso» (PE, $p .30$ ), esta equívoca regressão à mãe é também a nostalgia pela perda da individuação, a anulação da identidade autónoma que os olhos cegos simbolizam. E um enigma se destaca do jogo dramático: é este o retrato apenas do fantasmático incesto edipiano, ou antes de toda e qualquer queda amorosa, que por meio dele se perspectiva? o amor como prisão cega elou como cegueira iluminante?

Para a autora, existiu uma clara intenção alegórica a determinar a concepção desta obra que ela entenderá, retrospectivamente, não como peça teatral, mas sim como diálogo filosófico, «um processo dialógico de expor uma tese (...) que retoma o mito matrista». Em depoimento inédito prestado a Júlia Lello (1988), em torno do seu teatro, diz Natália ainda:

\begin{abstract}
Sófocles só representa o tratamento do mito na óptica patriarcal. $O$ meu Édipo cega-se para o exterior, onde vigora a lei patriarcal, que castiga o seu incesto, para se refugiar no seu inconsciente individual, que guarda a lei arcaica de iniciação do filho na sabedoria materna, através de incesto que, neste caso, é simbólico. Retomase pois aqui o mito da Deusa-Mãe e do filho que na tragédia grega é castigado pelo Deus introduzido pela cultura patriarcal indoeuropeia. (...) Dai eu chamar Progresso de Édipo-porque o Édipo e a Jocasta assumem o incesto, ao contrário do que se passa na tragédia grega. Pretendo repor ao mesmo tempo um estado prélógico, ou seja, pré-patriarcal (LELLO, 1988, p. 15).
\end{abstract}

As aporias de eros perante a formatação social e a aspiração utópica da vontade individual são questões que Natália desenvolve teatralmente numa peça notável que constituiria de facto a sua primeira obra de longo fôlego para palco escrita a solo: D. Joáo e Julieta (que se chamou, numa primeira versão, D. João e o espectro de Julieta), título que explicita o ágon que esta peça trava para com D. Joáo e a máscara (1924), a obraprima dramatúrgica de António Patrício, o mais poderoso e influente dos dramaturgos portugueses da primeira metade do séc. XX (ROSA, 2003). D. João e Julieta (1957/58) realiza o encontro português entre o personagem de Tirso de Molina e de Molière, revisto por António Patrício, e a Julieta de Shakespeare, agora reinventados num palco que oscila entre a alta comédia de Wilde, o lirismo simbolista e o drama existencial. Obra de divulgação póstuma (cuja primeira edição em livro, em 1999, tive a honra de prefaciar), a autora faria segredo deste encontro de mitos, sobre o qual paira a sombra de Electra, confiando o texto a João Mota em 1989, que o encenaria dez anos depois no Teatro da Trindade com a Comuna-Teatro de Pesquisa, num espec- 
táculo cenografado por José Manuel Castanheira, com Carlos Paulo e Ana Lúcia Palminha nos papéis titulares, e que integrou ainda a estreia do Auto da feiticeira cotovia, subtítulo de Comunicação, poemodrama de 1959, espécie de singular resposta nataliana à Mensagem de Fernando Pessoa.

o homúnculo - tragédia jocosa, peça editada em 1965 por Luiz Pacheco e logo apreendida pela PIDE (a polícia politica de Salazar), surgenos como a primeira obra de um conjunto de três peças para as quais proponho a designação de trilogia de mitos lusitanos, fundada em afinidades que me parecem irmaná-las, já que, sublinhe-se, nunca esta nomenclatura e este agrupamento textual fossem sugeridos pela autora. A pécora (1967) $e$ o encoberto (1969) são as outras duas obras que integrarão tal trilogia. Para além de serem textos que Natália comporá em sequência e proximidade cronológicas, a similaridade na concepção estilística dos títulos indicia logo à partida um parentesco que os temas desenvolvidos em cada um dos dramas confirmarão. A designação nominal, comum a cada uma destas peças, visa a colocar no palco, com intentos fabulísticos, imaginativos e provocatórios, mitos específicos da realidade histórico-política elou psicoreligiosa portuguesa. Assim, enquanto $O$ homúnculo se ocupou satiricamente com o automitificado ditador Salazar, já A pécora (AP) esconde uma virulenta parábola motivada livre e libertinamente pelo fenómeno controverso das apariçóes marianas de Fátima, em 1917; se bem que os dados dramatúrgicos utilizados se mostrem antes bastante mais próximos dos que envolveram as fraudulentas aparições de La Salette, em França, ocorridas em 1846, data próxima desse final do séc. XIX que vem a ser o tempo histórico-dramático da peça. Por sua vez, O encoberto será a criação teatral nataliana a dar voz ao mito sebastianista, para o ampliar no sentido de um messianismo universalista e ovniológico. Seria a sua primeira peça para adultos a subir à cena, no Teatro Maria Matos, com estreia absoluta em Ponta Delgada, em fevereiro de 1977, numa encenação de Carlos Avilez, com um vasto elenco liderado por Ruy de Carvalho no papel de Bonami-Sebastião, e um cenário memorável de Lima de Freitas, que traduzia visualmente a mundividência barroca da autora.

Concluída em 1967 e prestes a ser publicada nesse ano, numa edição que não se efectivou em virtude de a polícia política se antecipar na sua proibição, ameaçando "a tipografia que a imprimia (...) de fechar-lhe as portas» (AP, p. 9), A pécora só sairia finalmente em livro em 1983, nove anos depois da revolução de Abril. Natália justifica causticamente, em estilo muito seu, no prefácio à peça, esta espera demorada.

Tão caudaloso foi, nos júbilos de Abril, o cortejo de vítimas da censura, a besuntar de martírio a sua mediocridade, que, podendo 
ROSA, A. N. EROS, HISTÓRIA E UTOPIA:...

esta peça ser tudo o que quiserem, menos mediocre, tive por dispensáveis os bons oficios da grita que extrapolava a excelência das obras, do galardão de terem sido censuradas (AP, p. 9).

Com A pécora iniciava a autora um ciclo de peças extensas que contrasta, em formato e ambição dramáticos, com os breves experimentos logocénicos que anteriormente dera a conhecer. Em face do carácter altamente polémico do conteúdo da peça, é oportuno destacar a dedicatória que Natália endereça nela a Almada Negreiros (1896-1970), o mais polivalente, longevo e solar dos modernistas portugueses, que dividiu o génio entre a escrita, a pintura e as artes performativas (autor de célebres manifestos poético-panfletários, demolidores do status quo, como A cena do ódio e o Manifesto anti-Dantas), dedicatória esta partilhada ainda com o poeta $e$ ensaísta, amigo de Natália e seu admirador de sempre, David Mourão-Ferreira (1927-1996), um dos primeiros leitores d' A pécora "que finamente a reconheceu como filiada nos velhos mistérios representados por ocasião das festas litúrgicas» de quem "veio a sugestão de a intitular Auto da Paixão de Santa Melânià (AP, $p$. 10). Mas tal filiação litúrgica não deixa de o ser por viperina antítese. Natália regista a sugestão no prefácio, ainda que não tenha acatado esse conselho. O certo é que tal título nos tornaria mais visivel o duelo dramatúrgico que esta obra nataliana, farpa espetada nas perversóes do catolicismo, ensaia em certos aspectos para com uma das peças mais singulares de Bertolt Brecht (escrita com a colaboração de Elisabeth Hauptmann): A santa Joana dos matadouros (1931).

A influência brechtiana é de resto inegável em estratégias discursivas específicas, como o efeito de descontinuidade reflexiva e distractiva de trechos cantados elou recitados, bem como numa ambiguidade irónica da construção expressionista dos personagens, suspensa na alegoria sociocrítica e no sarcasmo paródico. Não obstante isso, a espiritualidade heterodoxa da autora reclama para a sua peça uma mensagem que não se confina ao materialismo dialéctico com que o Brecht épico didacticamente fundamenta as suas fábulas. No fôlego sulfúrico da peça, dirigido à hipocrisia eclesial, vê, porém, Natália «a sua profunda religiosidade; pois desta lhe emerge a desmistificação do mercado religioso que vende Deus em bentinhos, pagelas e outros artigos da comercialização da crendice.» (AP, p. 10). Entretanto, e apesar do que separa, em significação dramática, as personagens da combatente idealista Joana Dark e da "doce e puríssima prostituta" Melânia Sabiani (AP, p. 10), o percurso sacrificial desta última evoca a heroina brechtiana, pois ambas acabam por soçobrar rasuradas ante a crueldade e injustiça do mundo, contribuindo os outros personagens, individu- 
ais ou colectivos, da peça de Natália, para uma atmosfera cénica de catarse barroca e pathos grotesco, boschiano.

Aliás, a filiação barroca sobrepujará doravante, para a autora, a estética surrealista (sendo o surrealismo, por seu turno, uma metamorfose expressiva que eclode da mundividência simbolista, como Artaud o manifesta exemplarmente) que estimulara a sua obra dramática nesses primórdios correspondentes às duas parcerias com Manuel de Lima; peças estas a quatro mãos que separamos aqui da distinta orientação estética manifestada pelos primeiros dois dramas a solo de Natália, fortemente enraizados no húmus, a um tempo lírico e cerebral, dos simbolistas: D. Joáo e Julieta e $O$ progresso de Édipo.

É um teatro que se sabe excessivo em si mesmo, e projecta na linguagem a pulsão imagética em proliferação, como uma volúpia verbal e cénica, adversa a contençóes classicistas. Dai a multiplicação constante de personagens e figurantes (em registo análogo ao que acontecerá depois n' $O$ encoberto e em Erros meus, má fortuna, amor ardente), que colectivamente concorrem para a reinvenção do grande-teatro-do-mundo da alegoria calderoniana. E nem por acaso o trajecto desse pensador maior do drama barroco, que é Walter Benjamin, estabelecera a ponte crítica entre o Trauerspiel barroco (como distinto da tragédia clássica) e a concepção épica brechtiana, cuja presença se detecta nesta peça de Natália. Se bem que o trágico desfecho d' A pécora aponte para um modelo (artaudiano) de catártica crueldade que convive com o estranhamento sociocrítico (brechtiano), numa fórmula convergente à de uma obra dramática sua contemporânea, que Peter Brook encenava então de Londres para Nova Iorque (1966), enquanto em Lisboa Natália escrevia A pécora: refiro-me a Marat/Sade, de Peter Weiss. Na conjunção das influências, e da superação delas pela voz própria autoral, Carlos Porto detectaria ainda n'A pécora uma possivel e paradoxal sintese que a autora aqui realizaria entre o sociocentrismo brechtiano e o ritualismo blasfemo e neobarroco de Genet (REBELLO, 1989, p. 144).

Sobre a sua predilecção pelo barroco, diz a autora:

\begin{abstract}
[o meu teatro], embora tenha alguma coisa a ver com o surrealismo, tem muito mais a ver com a tradição ibérica. A minha atracção pela estética barroca, que tem raizes peninsulares, portanto portuguesas, é que me aproxima do teatro ibérico de expressão espanhola, onde eu encontro libertas e estuantes linhas de força que, na dramaturgia portuguesa, por um preconceito anti-castelhano, estão abafadas. (...) Os [autores] que eu encontro mais próximos do meu teatro são Calderón, Lope de Vega, Tirso de Molina. Valle Inclan ainda continua essa tradição... (LELLO, 1988, p. 15).
\end{abstract}


E de Lope de Vega chega mesmo Natália a ser não só tradutora como também dramaturgista recriadora, responsável por uma versão pessoal de Fuenteovejuna, ampliada com trechos poéticos a ser musicados, texto mais uma vez proibido pela censura, que irá estrear a Barcelona em 1973 com o Teatro Experimental de Cascais (companhia fundada em 1965), numa encenação de Carlos Avilez, iniciando-se aí uma colaboração longa e frutuosa entre este encenador e a dramaturga, que se prolongaria para além da morte desta.

Numa dialéctica divisão em três actos, de que a escritora nunca prescindirá nas suas peças longas a solo, A pécora desenrola-se em oito episódios, que são aqui sinónimo de quadros cénicos distintos, decorrendo a acção "durante as duas últimas décadas do século XIX»; o lugar dramático é uma fantasia alegórica (tal como a Mortocália onde decorria O homúnculo) Chamada "Gal, velho burgo encravado no centro de um país da Europa meridional, cujo nome deixamos ao público a escolha (...), desde que não seja deslocado deste clima do sol do Meio-Dia.» (AP, $p$. 17). o prólogo em verso, recitado por três mulheres galesas, dá-nos a saber o suposto fenómeno sobrenatural acontecido naquelas paragens, que fez de Gal um lugar de peregrinação fervorosa: "Não digas, ó pecador / que os milagres são mentira! / Que um anjo andou pela terra / e raptou uma donzela / dois pastorinhos o viram ...» (AP, $p$. 18). A fama sagrada do sitio, que levou a que se erguesse ali um oratório, esconde, porém, um sórdido embuste, que só será inteiramente revelado ao espectador no $2^{\circ}$ episódio, quando a protagonista Melânia, cujo novo mester dá nome à peça, é acolhida como recémchegada aprendiz de "pécora", no bordel de Madame Olympia. A jovem Melânia (cujo nome Natália foi decerto buscar à pessoa de Melanie Calvat, uma dos dois "videntes» envolvidos no embuste de La Salette), também chamada Pupi, mantinha um romance secreto com um padre, mas duas crianças, dedicadas ao pastoreio, surpreenderam um flagrante do casal em cenário campestre, pelo que os amantes terão de inventar um estratagema para não serem denunciados pelos miúdos. o padre seria então um anjo e Melânia uma santa escolhida. É a própria que o explica a Teófilo Ardinelli, um rufia astuto frequentador do prostíbulo, de quem ela foi outrora noiva.

MELÂNIA: (de olhos no chão) O anjo ... é o padre Salata. ARDINELLI: Olá! Esse padre afinal saiu-me um bom pássaro. Preparou o golpe do milagre para explorar os peregrinos. MELÂNIA: Eu tinha que vir para a cidade sem deixar rasto. E isto só era possível se pensassem que eu tinha ido para o céu, que é um sítio onde ninguém nos vai procurar. Foi quando o padre Salata teve a ideia de se servir das duas crianças e disse-me: "Chegou a altura de não decepcionarmos os aborrecidos pastorinhos que não 
te deixam em paz desde que lhes disseste que eu era um anjo." Estou muito arrependida. Mas aquelas crianças eram tão curiosas. Ouviram vozes nas ruínas e quiseram saber o que se passava. Prometi-lhes que, se guardassem segredo, seriam recompensadas com a celeste visão. E foram. Quando o ventre começou a incharme (gesto de indignado assombro de Teófilo Ardinelli), anuncieilhes: "Chegou o dia. Ides ver o anjo que vem para me levar ao céu. Fostes eleitos para testemunhar o prodígio porque a voz da inocência é o clarim que Deus escolhe para proclamar as suas maravilhas." E assim foi.

ARDINELLI: (colérico) Quer dizer que tu e esse Casanova de sotaina fizeram de mim o maior corno de Gal. Estou pior que um leão e tu vais fazer companhia aos dois Regedores... (Lógico, falando para si.) o que aliás é conveniente porque, se os devotos descobrem que a santa é este caixote de lixo, lá se vai o maior centro turístico da Europa (AP, p. 55-56).

Mas os instintos vingativos logo abrandarão neste Teófilo femeeiro, que julgava a noiva no paraíso e encontra-a agora no bordel. A sua amoralidade hedonista sente-se gratificada: "Eu sempre disse que os prostibulos são o único paraíso a que devemos aspirar, porque é neles que se alcança a liberdade.» (AP, p. 59). O núcleo de enredo da peça encontra-se assim desvelado; são dois os níveis dramáticos em que A pécora se desenvolve: um, o dos populares e forasteiros que pela sua fé acorrem a $\mathrm{Gal}$, em romagem de agravados, e que nem sonham a origem fraudulenta do milagre que deu fama ao lugar; por outro lado, o nivel ocupado por aqueles que sabem ou suspeitam da intrujice, mas exploram de forma oportunista o filão comercial, e de angariação de devotos para a Igreja, em que se torna o culto dessa santa raptada pelos céus. Desde logo, Melânia é uma personagem que não terá morada em nenhum desses dois niveis; refugiada num bordel, ela é a figura supérflua, cujo papel a cumprir já foi desempenhado, $e$ a quem só restará a progressiva erosão da identidade, ainda que seja chamada uma última vez para o milagre decisivo de aparecer em suposta levitação ante uma multidão atónita e crédula, que inclui eclesiásticos e até um sociólogo, subitamente convertido pela ilusão espectacular do truque. Será esta a maior manobra ilusionista dos que fazem prosperar o negócio, na empresa "Ardinelli \& Tricoteaux, Investimentos em Gal», cuja eficaz e zelosa funcionária, Zenóbia de seu nome, não deixa ao acaso o mais ínfimo pormenor para fabricar a hagiografia da santa fictícia. Até mesmo um actor é convocado para tornar mais impressionantes as curas milagrosas experimentadas pelos crentes em Gal. Oportunidade para Natália colocar na máscara deste actor (que Zenóbia, sem perceber "nada de teatro» desconfia ser um "canastrão», AP, p. 89) uma concepção sofistica que, invocando Diderot, 
se emula ironicamente à lição do distanciamento brechtiano; antecipando aqui o tema abismal do teatro dentro da vida, que está, por sua vez, dentro do teatro, e será motivo dramático central n' O encoberto, a peça seguinte desta, por mim designada, trilogia de mitos lusitanos.

O ACTOR: O teatro é a arte da insensibilidade. Diderot o disse: Os choróes fazem má figura no palco. A predilecção por um papel éo sinal de uma sentimentalidade que só o actor mediocre conhece. o meu repertório é tão vasto quantas as causas que a miserável Humanidade a que chamamos plateia exige ao actor para verter lágrimas. Escolham! (Jerónimo Tricoteaux levanta a cabeça dos papéis e observa.) Começarei pelo ladrão arrependido (AP, p. 68).

Peça truculenta, de muitos e fortes ingredientes teatrais, que detém alcance hierológico, nela ressalta esse profundo desagrado nataliano por um cristianismo oficioso que usa o suplício do crucificado, e não a libertação do ressuscitado, para subjugar os indivíduos à autoridade eclesial, aliada que se faz dos poderes económicos para implantar o seu muito terreno império. Uma frase de um coro de padres, diante da multidão de doentes e flagelantes, é bem a divisa deste poder castrante: "Sofrei, sofrei, enfermos e pecadores! É a dor que reune os átomos do efémero mundo." (AP, $p$. 102). Diagnóstico afinal proveniente dessa sabedoria sombria de séculos que a doutrina teológico-clerical acumulou acerca das fraquezas da condição humana, de forma a melhor conseguir manipulá-la. Uma estrofe em solilóquio, dita pelo Cónego (no episódio IV, que decorre na sacristia com um diálogo entre prelados), será talvez a melhor síntese expressiva que na peça aborda a motivação existencial do despotismo patriarcal monoteísta.

CÓNEGO: (para si) Ó miserável condição humana que te exprimes nos sons celestes da música! É de te ouvires a ti próprio, ó homem, que estás vivo e te espreguiças para Deus! Retirem-te essa ténue luz na hora da morte ou das aflições e na taça da tua memória beberás a penumbra do verme (AP, p. 90).

A ascendência teatral ibérica, reinvindicada pela autora, faz-se sentir na caricatura tipificada, num tipo fársico que chamamos hoje de expressionista, mas que encontramos, por exemplo, no humor do teatro vicentino. Disso são exemplos os retratos do Sociólogo e do Cientista, este último 
uma florescência do evangelho positivista, que, por isso mesmo, se orgulha de ter escrito uma obra que tem por longo e hilariante título: "O delírio crónico de Jesus explicado por uma avitaminose no qual se prova que a Sua morte foi provocada por um derrame plêurico"; porque, justifica-se o Cientista, "os místicos são sempre esfomeados.» (AP, p. 113).

o terceiro acto decorre trinta anos depois da acção anterior, já no séc. XX. No café que é propriedade da antiga prostituta cantora Domicella, estamos no dia solene e festivo em que a Igreja declara a canonização de Santa Melânia, subida aos céus. Mas eis que surge no bar Melânia ela mesma, envelhecida e decadente, perseguindo Paco, um jovem chulo a quem ela mendiga amor, e que a despreza. No proscénio, recitará ela, sob o fundo dissonante dos carrilhões que comemoram a "sua» canonização, um poema de cabaré contando a história dos seus desamores de santa meretriz, que não desmereceria a música de Weil ou de Eisler. Entram depois Paco e quatro marinheiros que a lançam em braços uns para os outros, enquanto entoam a célebre cantilena dos piratas da Ode maritima de Álvaro de Campos: "Fifteen men on the Dead Man's Chest / Yo-ho and a bottle of rum!». Termina este VI episódio com um novo recitativo autobiográfico de Melânia sozinha em cena, outra vez no proscénio, dotada de uma dignidade patética que o amor enobrece. Melânia nunca deixou de amar os que a exploraram fingindo amá-la porque, começa ela: "Neste baixo mundo de sonho / só o impossivel amor é real»; e vai repetindo ao longo de uma fala que bem pode ser vista ao modo de balada melancólica: "Quantos enriqueceram com o meu altar?»

E quem mais enriqueceu foram provavelmente Teófilo e Zenóbia, agora casados em consórcio financeiro, formando um casal azedo, nos quais a velhice trouxe à superficie o pior dos caracteres de cada um. Têm um filho jovem que aparece como a consciência julgadora dos pais, contestatário da ascendência que o gerou. Por meio dele, Natália problematiza de novo o mito fundador edipiano.

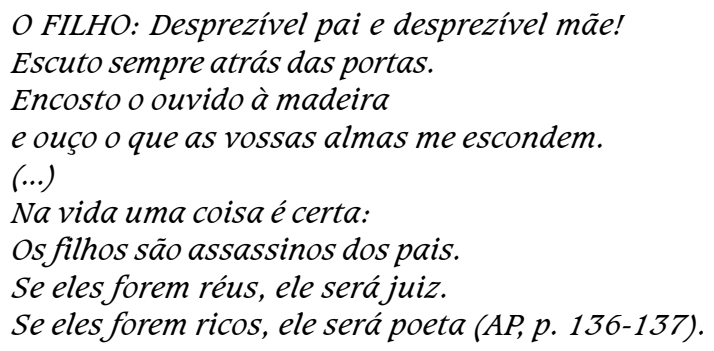


Zenóbia e Ardinelli ficam coléricos quando o seu sócio Tricoteaux os informa de que Melânia se encontra na cidade nesse dia de pompa, num momento em que a crueldade de Teófilo pensaria que ela «já devia ter expirado há muito no catre de um hospital da Assistência Pública» (AP, p. 139). E Paco surgirá na companhia de Melânia, com o intuito de chantagear Zenóbia e Teófilo, dando a entender que divulgará o embuste, pois "certos órgãos de imprensa hão-de gostar de saber que esta mariposa do cais, que queimou as asas nas torpes paixóes dos homens, é a santinha de Gal...” (AP, p. 147). Teófilo acaba por apertar a mão a Paco, num acordo negocial que é a simbólica sentença de morte para Melânia. No VIII e último episódio, rodeados pelo coro de enfermos peregrinos de Gal, Paco e Melânia jogamo seu derradeiro encontro. Uma vez com dinheiro nas mãos, o mafioso Paco repudia a desgraçada Melânia, visto que não quer, diz ele: «repartir o meu dinheiro com essas carnes engelhadas quando com ele posso comprar todas as virgens do mundo" (AP, $p$. 162). Abandonada e traída, Melânia enfurecese com a ladainha dos crentes que povoam o espaço da cena, não resistindo ao gesto perigoso e autodestrutivo de revelar uma verdade que ninguém deseja nem suportará ouvir.

MELÂNIA: Não haverá futuro! A teta da santa está seca. Para eles, é o fim do mundo. Oh, como todos vão rir! Como todos vão rir! (Abrindo os braços e exibindo-se canalhamente.) Vejam-na! Vejam-na! Uma cadela das docas!

(...)

Uma puta! A vossa santa é uma puta (AP, p. 165).

A multidão furiosa, que inclui cegos e aleijados, flagelantes e doentes de maca, mulheres estéreis e pagadoras de promessas, encarregarse-á de a agredir, para lhe abafar a voz, no climax violento e trágico da peça. Melânia, antes de sucumbir ensanguentada, fará um esforço ainda para proclamar que a verdadeira santa é ela e não aquela imagem pintada diante da qual todos se prostram. Serão essas as suas últimas palavras. A peça encerra com a apoteose barroca do cortejo da procissão, minuciosamente descrita pela autora, que irrompe em cena, e no qual todos pisarão impassivelmente o cadáver dela, incluindo o Cardeal e os Arcebispos, enquanto o hino em louvor da santa forjada é colectivamente entoado.

Sendo a mais iconoclasta e herética das peças teatrais que Natália escreveu, A pécora tem sido não raro considerada a mais excepcional de todas elas (aferição comparativa na qual estão ausentes os dramas póstumos). É o caso, por exemplo, de Luiz Francisco Rebello, para quem A pécora é «uma obra-prima da dramaturgia portuguesa contemporânea, não só pela 
perturbante novidade dos caminhos que ousa explorar como pela carga prodigiosa de imaginação a que dá livre curso» (AP, $2^{a}$ edição, texto de contracapa). Reforçando a qualidade indiscutivel que caracteriza a energia dramática do texto, o destaque crítico de que é alvo parece hoje indissociável da sua auspiciosa estreia cénica em 20/10/1989, isto é, do facto de ser A pécora, como o observou Fernando Dacosta, "um dos grandes êxitos do teatro português pós-25 de Abril» (DACOSTA, 2000, p. 130), que permaneceu meio ano em palco, numa encenação de João Mota, para a Comuna-Teatro de Pesquisa (companhia fundada em 1972); e que constituiu simultaneamente a única internacionalização que o teatro nataliano conheceu em vida da autora, dado que o espectáculo, integrado no I Festival de Teatro da então recém-fundada Convenção Teatral Europeia, fez digressão por palcos de França (St. Ettienne e Paris) e da Irlanda. A pécora proporcionaria ainda uma interpretação premiada à actriz Manuela de Freitas, no papel da protagonista. A encenação e a concepção cénica de João Mota permitiram uma leitura rude e vigorosa da peça, ao transportar os espectadores para o espaço rural dos autos populares, sobre um chão de terra crua; estando a criação musical a cargo de José Mário Branco, cantor e autor de intervenção política, que compusera no exílio em 1971 a música para um emblemático poema de Natália, que graças à canção viria a tornar-se justamente um dos mais popularizados da autora: Queixa das almas jovens censuradas (1957). Como escreveria Carlos Porto, numa retrospectiva sobre esta companhia, datada de 1998:

provavelmente, o espectáculo da Comuna que obteve uma maior, calorosa, entusiástica adesão do público foi A pécora, texto de Natália Correia. (...) O sucesso de público e de crítica desse espectáculo pode medir-se pela reacção (...) [de] Yuri Liubimov, director da célebre companhia Taganka, (...) [que] considerou A pécora o melhor espectáculo que pudera ver desde há muito tempo (COMUNA, 1998, p. 187).

Mas tal não deve fazer-nos esquecer a importância de outras obras natalianas, como é o caso do libreto operático Em nome da paz, trazido de novo à luz pela investigação de Eugénia Vasques em torno das dramaturgas novecentistas, e que provocara, em 1978, uma das mais conturbadas recepções públicas de que há memória no Teatro Nacional de São Carlos, em Lisboa, entre vaias iradas e aplausos entusiásticos; uma obra que pelo tema e pela polémica suscitada é bem comparável com A decisão (1931) de Brecht. Nem deve permitir que subestimemos Erros meus, má fortuna, amor ardente, a peça camoniana de Natália, que é acima de tudo uma luxuriante 
celebração da língua, pela recriação/reinvenção de um português falado por Camóes e seus contemporâneos, que fosse digno de dar voz ao vate $e$ receber intertextualidades de poemas e dramaturgia de Camóes ele mesmo. Após um boicote económico sofrido em 1980, que a impediu de ser produzida no Teatro Nacional D. Maria II, a peça seria encenada por Carlos Avilez em 1988, em Lisboa, com a sua companhia do Teatro Experimental de Cascais (TEC), no Centro de Arte Moderna da Fundação Calouste Gulbenkian, graças à vontade decisória de Madalena Perdigão, que tornou possível uma superprodução teatral (com Rogério Samora em Camões, Alexandra Lencastre em Catarina de Ataíde, Lia Gama em Infanta D. Maria, e Filipe Crawford em D. Sebastião, num elenco de mais de trinta actores, cenografia de Emília Nadal, e música de Carlos Zíngaro).

o testamento dramatúrgico de Natália, Auto do solstício do inverno (1989), foi por ela oferecido em gratidão autoral a Carlos Avilez, sendo por este encenado em 2005, uma vez mais com o TEC, no Teatro Mirita Casimiro, em Cascais, com cenografia de Fernando Alvarez, música de Pedro Vasconcelos e, entre o colectivo de intérpretes, Fernanda Neves, António Marques, Sérgio Silva, e Anna Paula, num alter ego da própria autora, que o encenador projectou nas fulgurantes falas poéticas de uma mulher do coro de camponesas. Citando a forma vicentina de auto, Natália despede-se em teatro com a mais univoca e explicitamente localizada das suas peças, no sentido geográfico português; numa aldeia de Trás-os-Montes onde subsiste a tradição dos caretos, uma mascarada ritual de origem pagã que coexiste no calendário com as festividades do Natal cristão. Peça de espantosa concisão e maturidade cénicas, nela se articulam os temas centrais do teatro nataliano: os fantasmas de eros no coração do drama; o apelo de uma ancestral sageza matriarcal; a denúncia da hipocrisia dos poderes financeiro-politicos; e a busca de uma gnose espiritual greco-cristã, liberadora do sujeito, que transcende os dogmas das religiões instituidas.

\section{RESUMO}

De entre uma vasta obra literária, distribuída pelos mais diversos géneros, a criação dramatúrgica de Natália Correia ( $S$. Miguel/Açores, 1923 -Lisboa, 1993) é um núcleo fundamental para avaliar a importância do seu legado artístico, que é veículo, em Natália, de uma atitude experimental e provocatória, em demanda publicamente íntima e de autognose, ético-política, e espiritual no seu mais amplo sentido. Este ensaio pretende oferecer uma perspectiva sequencial de Natália Correia dramaturga - dando inclusive algum destaque a peças teatrais menos conhecidos da autora-que revele o quanto os palcos de 
hoje têm a beneficiar do confronto com a inventiva poética do seu teatro escrito.

Palavras-chave: Natália Correia; dramaturgia portuguesa do século XX; arte teatral e censura politica.

\section{ABSTRACT}

Among the great diversity of the literary works by Natália Correia (S. Miguel/Azores, 1923 - Lisbon, 1993), playwriting is a fundamental sphere through which we can assess the importance of her artistic legacy, one that carries within the experimental and provocative attitude of the author, in an intimate and public quest for ethical, political, and spiritual self-knowledge, in the broader sense of the word. The present essay intends to offer a sequential perspective of the playwriting by Natália Correia in addition to attending to some of her less known plays - that will attempt to show how the theatre stage of today can benefit from the confrontation with the inventive poetics of her playwriting.

Key words: Natália Correia; Portuguese theatre of the 20th century; drama as art and political censorship.

\section{REFERÊNCIAS}

BRECHT, Bertolt. A Santa Joana dos Matadouros [1931]. Tradução e introdução de Roberto Schwarz. São Paulo: Paz e Terra, 1997.

COMUNA - Teatro de Pesquisa. 25 anos: $1972-1997$ (volume antológico). Lisboa: Comuna Teatro de Pesquisa, 1998.

CORREIA, Natália. A pécora. Lisboa: Dom Quixote, 1983.

Auto do solstício do inverno. Dactiloscrito inédito. Cascais: Teatro Experimental de Cascais, 1989

D. João e Julieta [1957/58]. Prefácio de Armando Nascimento Rosa. Lisboa: SPA/ Dom Quixote, 1999.

Em nome da paz. Libreto de ópera com música de Álvaro Cassuto [dactiloscrito de 1972-3]. Lisboa: Teatro Nacional de S. Carlos, 1978.

Erros meus, má fortuna, amor ardente. Lisboa: Afrodite, 1981.

O encoberto [1969]. 3. ed. Lisboa: Afrodite, 1977.

o homúnculo - tragédia jocosa. Lisboa: Contraponto, 1965.

o progresso de Édipo. Poema dramático. Lisboa: edição de autor, 1957.

Poesia completa. O sol nas noites e o luar nos dias. Lisboa: Dom Quixote, 1999. 
ROSA, A. N. Eros, história e utopia:...

CORREIA, Natália; LIMA, Manuel de. Dois reis e um sono. Há grande complicação na corte do mandrião. Dactiloscrito inédito. Lisboa: Biblioteca Nacional, 1958.

Sucubina ou a teoria do chapéu, peça em quatro actos. Dactiloscrito inédito. Lisboa: Biblioteca Nacional, 1952.

COSTA, Ana Paula. Natália Correia - Fotobiografia. Lisboa: Dom Quixote, 2005.

DACOSTA, Fernando. Nascido no Estado Novo. Lisboa: Notícias, 2001.

LELLO, Júlia. Esboço para uma dramaturgia sobre seis peças de Natália Correia, ou uma epopeia crítica da mátria. Lisboa, 1988. Dissertação (Disciplina de História da Literatura Dramática). Conservatório Nacional/Escola Superior de Teatro e Cinema.

REBELLO, Luiz Francisco. História do teatro português. 4. ed. rev. e aum. Mem Martins: Europa-América, 1989.

ROSA, Armando Nascimento. As máscaras nigromantes - uma leitura do teatro escrito de António Patrício. Lisboa: Assírio \& Alvim, 2003.

Rostos de Narciso - Sobre D. João e Julieta, de Natália Correia. Disponível em: $<$ http://www.triplov.com/teatro/armando_nascimento_rosa/Rostos-de-Narciso/ rostos.html>. Acesso em: 2006.

SANTOS, Manuela Gonçalves dos. (Des)Crucificações. Público, Lisboa, o1 out. 1993. Suplemento Leituras, p. 2 .

VASQUES, Eugénia. Mulheres que escreveram teatro no século XX em Portugal. Lisboa: Colibri, 2001. 